\title{
Bracia miesiące: świadectwo sprawców
}

Joanna Tokarska-Bakir

TEKSTY DRUGIE 2018, NR 3, S. 42-56

DOI: $10.18318 /$ td.2018.3.3

\section{Baśń typu 480}

Bracia miesiace to tytuł baśni typu $480 \mathrm{w}$ klasyfikacji Aarnego-Thompsona, ,the kind and the unkind girls"'. W wersji Janiny Porazińskiej opowiada ona o kobiecie, która miała córkę i pasierbicę. „Pasierbica była dobra, a córka była dokucznica. Pasierbica zawsze miała główkę gładko przyczesaną, liczko umyte, sukienkę, choć biedniutką, ale czystą. Córka była roztargana, często nieumyta, a jak jej się spódniczka ubłociła, to w takiej szargulicy wciąż chodziła"2.

Oczywiście zupełnie inaczej niż Porazińska widziała to macocha, która właśnie schludnej pasierbicy chciała się pozbyć. Więc kiedy przyszła zima, wysłała ją do lasu po fiołki., Jak ich nie nazbierasz, to się tu nie pokazuj, bo cię do izby nie wpuszczę"”.

1 G.A. Megas Folktales of Greece, University of Chicago Press, Chicago-London 1970, S. 123

2 Zob. http://bibliotekazsw.jcom.pl/images/pliki/O_dwunastu_miesiacach.pdf?i=2 (10.2.2018).

3 Tamże. 
Sierota idzie, oczy wypłakuje. Naraz widzi ognisko, a dookoła siedzi dwunastu mężczyzn. Spytali ją, czego szuka w taką zawieję. Opowiedziała, a wtedy Kwiecień przesiadł się na miejsce Grudnia i fiołki się znalazły. Macocha wysłała ją jeszcze raz po poziomki, i po jabłka. Na koniec sierota przystała do Miesięcy na służbę, a wysłana jej śladem zła córka gospodyni przepadła w zamieci.

\section{Dirty warriors}

Zaczęłam od tej baśni dla przywołania porządku symbolicznego, o którego rozpadzie mowa w artykule pt. Bracia miesiace, nad którym pracuję. Opiera się on na materiale kilkunastu powojennych procesów o mordy na Żydach popełnione w latach 1943-1945 na południowej Kielecczyźnie, w rejonie wyznaczonym wierzchołkami trójkąta Koprzywnica - Sędziszów - Kazimierza Wielka ${ }^{4}$.

Żydów mordowali tu „dirty warriors” skich i Armii Krajowej, w okresie zbliżenia tych organizacji, czyli od lata 1943 do marca 1944, tzn. do sfinalizowania umów o podporządkowaniu pierwszej tej drugiej. Wszyscy sprawcy należeli do dwóch formacji samoobrony $^{6}$ obu tych organizacji - w BCh określających się jako Korpus Bezpieczeństwa i Ludowa Służba Bezpieczeństwa, w AK do formacji dywersyjnych, w tym szczególnie jednej o kryptonimie „Dominik” (czasem też w dokumentach: „Dominika”).

4 Wzmianki o mordzie w Chruszczynie Wielkiej pojawiły się np. w tekście Jana Grabowskiego "Chcę nadmienić, że nie byłem uświadomiony i wykonywałem zadanie jako żołnierz Armii Krajowej". O wymordowaniu ukrywających się Żydów przez kompanię miechowskiej AK, "Zagłada Żydów. Studia i materiały" 2010 t. 6, s. 207-237, wzmianka na s. 215, z powołaniem się na zlokalizowaną przez Alinę Skibińską teczkę AIPN GK_306, teczka 32, Sąd Wojewódzki w Kielcach.

5 Określenie "dirty warriors" oznaczające żołnierzy posłusznych rozkazom, popełniających zbrodnie przeciw ludzkości, zostało zaczerpnięte z kontekstu argentyńskich szwadronów śmierci. Upowszechnił je Mark J. Osiel, zob. tegoż Contructing subversion in Argentina's Dirty War, "Representations" $2001 \mathrm{nr}$ 75, s. 119, 140; tegoż The mental state of torturers: Argentina's Dirty War", w: Torture. A Collection, ed. by S. Levinson, Oxford University Press, New York 2004. Zob. także definicja Johna P. Reedera Jr, który pisze że "dirty warriors" to "perplexed actors who did their duty as they saw it", J.P. Reeder Jr What kind of person would be a torturer, "Journal of Religious Ethics" 201038 (1), przyp. 10, s. 70.

6 Kategoria samoobrony/milicji obywatelskiej (vigilantism) pojawia się często w klasyfikacjach przemocy zbiorowej, zob. np. R.S. de la Roche, Modern Lynching, w: Violence. From Theory to Research, eds. M.A Zahn, H.H. Brownstein, S.L. Jackson, Anderson Publishing, Virginia 2004, S. 215. 
Jeden z żołnierzy tej ostatniej formacji zeznawał: „oddziały «Dominika» to były oddziały wydzielone z organizacji AK, których zadaniem było, oprócz walki z okupantem, likwidowanie Żydów"'.

\section{Nazwiska sprawców}

Sprawcy noszą często nazwiska odmiesięczne - południowa Kielecczyzna jest ich wyspą. Mamy tu zatem Aleksego i Tadeusza Stycznia, Franciszka Lutego, Jana Marca, Tadeusza Kwietnia, Jana i Stefana Maja, Władysława i Stanisława Czerwca, Jana Lipca, Anastazego Sierpnia, Konstantego Września, Edwarda Grudnia i wielu innych.

\section{Scena zbrodni}

Teren, o którym mowa, bywa określany jako polski matecznik. „Mam wrażenie, że chcąc zobaczyć obszar odpowiadający polskiemu jądru", trzeba pobłądzić gdzieś „między Krakowem a Warszawą”, pisze Ziemowit Szczerek .

Intuicję tę potwierdza bogaty materiał etnograficzny zawarty w przesłuchaniach procesowych, które przynoszą drastyczny obraz okupacji, w tym przechowywania i mordowania Żydów na kieleckiej prowincji.

W śledztwach raz po raz daje o sobie znać archaiczna wieś z jej kulturą materialną i coraz mniej zrozumiałym językiem.

„Dostałem rozkaz od Naczelnika Straży Pożarnej, by usunąć Żydów”, ukrywających się przy brodle dworskim, czyli wiacie na słomę - zeznaje jeden z partyzantów.

7 Przesłuchanie podejrzanego Bronisława Gazdy, s. Wojciecha i Zofii Maj, ur. 21.8.1923 w Nagorzanach pow. Pińczów, 17/6/1950, Mikrofilm z akt śledztwa przeciwko Bronisławowi Gaździe, s. Wojciecha, ur. 21.8.1923, i innym, Ki_0_27_165, k. 198.

8 Zob. http://wyborcza.pl/magazyn/1,153917,20538288,tylko-frajerzy-wierza-w-demokracjeziemowit-szcze rek-podrozuje.html\#TRwknd (11.2.2018).

9 Zeznanie świadka Bolesława Stasika (wszędzie ortografia oryginalna): „Władze gromadzkie kazały usunąć żydów z terenu. Poszliśmy w teren w Nagórzańskie Pole. Przy brodle dworskim byli żydzi [...] Oskarżony Grudzień wyjaśnia: Dostałem rozkaz od Naczelnika Straży Pożarnej, by usunąć Żydów. Było to gdy Giermańcy najeżdżali. Ilu tam żydków było, nie wiem", Ki_126_352, k. 275. Analogiczne akcje strażaków odnotowano na terenie gminy Zakościele pow. Mościska; wpis w karcie ewidencyjnej Kazimierza Gawlika, s. Kazimierza i Marii Szubka, ur. 10.7.1903 w Zakościelu: „jako członek straży pożarnej brał udział włapankach na żydów, oddając ich w ich ręce Niemców", kartoteka ogólnoinformacyjna MSW, AIPN BU_2911_1. 
Inny przypomina specyficzne nazewnictwo tych części obejścia, gdzie najczęściej ukrywano Żydów.

„W chlewie”"10. W oborze: „wchodziło się drzwiczkami zrobionymi w żłobie"11.

„W zapolnicy w stodole” - „zapolnica” to przegroda z desek oddzielająca zapole od klepiska; a „zapole" to miejsce na zboże w stodole, sąsiek ${ }^{12}$.

Pojawiają się niemal niezrozumiałe nazwy fantów, dla których Żydów łapano: „będzie cukier za niego”³. Inne trofea: kurtka na watolinie, skóra miękka i twarda na buty ${ }^{14}$, kapy pluszowe na łóżko, jesionka z bobrowym kołnierzem, płótno białe i szare, karbid do lamp.

Wychodzi na jaw wysoka kompetencja sprawców w zabijaniu (najlepsze do bicia są „kije wiśniowe"15 lub „kije świerkowe”) ${ }^{16}$, wiedza o tym, gdzie trzeba strzelić, żeby ofiara nie krzyknęła („w ucho”) i jak zamaskować grób („zasiać seradelę"17).

\section{Społeczny status sprawców}

Kto konkretnie jest sprawcą tych mordów? Nie są to wcale czy raczej nie wyłącznie jacyś demoniczni „ciemni chłopi” (za definicję ciemnoty przyjmując

10

\footnotetext{
Protokół przesłuchania podejrzanego Stanisława Czerwca, 28.4.1950, AIPN Ki_0_27_165, K. 153.

Przesłuchanie Władysława Pabisa, 15.6.1950, AIPN Ki_126_351, k. 106.

Wyrok Sądu Wojewódzkiego w Kielcach, 11.1.1951, AIPN Ki_126_353, K. 70.

Datowany na 15.4.1954 list redaktora "Gromada. Rolnik Polski" do Prokuratora Powiatowego W Iłży: „Czytelnik nasz, nie podając swego nazwiska, zam. w Kolonii Miechowa pow. Kazanów, pisze w swoim liście, że Kowalczyk Jan wydał w czasie okupacji Żyda w ręce Niemców. Kowalczyk zobaczył około dwudziestoletniego Żyda, który uciekał ze wsi Ozuchowa w stronę lasu i dogonił go w kanałach po torfie. Przyprowadził go następnie do Kolonii Miechowa, gdzie sołtysem był ob. Wiącek Józef, przy czym Kowalczyk wyraził się «będzie cukier za niego», i zaprowadzil Żyda do Kazanowa, gdzie Niemcy zabili go na podworzu Ostrowskiej". Akta sprawy karnej przeciwko Kowalczyk Jan, Wolski Stefan, Wiącek Józef osk. z art.1 pkt. 2 Dek. z dn. 31.8.1944, AIPN Ki 9_99, k. 13.

AIPN Ki_0_27_165, K. 156, 153.

Akta śledztwa [...] prowadzonego przeciwko Feliks Świerczyński i inni, AIPN Ki_0_13_1138_t1, k. 105.

AIPN Ki_0_13_1138_t2_cz1, k. 23.

Do Prokuratury Wojewódzkiej, Wydział Śledczy. Meldunek, 25.8.1952, AIPN Ki_0_13_1138_t1, k.105.
} 
brak wykształcenia). Są to rolnicy, ludzie zorientowani politycznie ${ }^{18}$, przedwojenni członkowie SL, czytelnicy ludowego pisma "Szarotka”, w czasie okupacji najpierw w organizacji „Racławice”, potem w BCh i AK. Sporadycznie (tylko w Sędziszowie) podlegają wpływom Stronnictwa Narodowego i księdza przed wojną wzywającego do bicia Żydów ${ }^{20}$.

Organizacją kierują wszędzie wiejskie elity, ludzie o wyższych kompetencjach zawodowych i społecznych: przed- i powojenni policjanci (np. Marian Grombala $^{21}$; Jan Ryczko ${ }^{22}$; Władysław Janowski³), przedwojenni wojskowi (np. Antoni Jarosz ${ }^{\mathbf{2 4}}$ czy Wacław Tutak ${ }^{\mathbf{2 5}}$ ), listonosze (Jan Osemlak) ${ }^{\mathbf{2 6}}$, agronomowie (Stanisław Czerwiec) ${ }^{\mathbf{2 7}}$.

18 Przesłuchanie Feliksa Świerczyńskiego, 16.12.1952: „do 1941 otrzymywałem prasę [...]. Z początkiem 1942 Kubaś przyniósł prasę, która głosiła o tworzeniu się organizacji chłopskiej Stronnictwa Ludowego. Ja z Kubasiem uzgodniłem, że tę prasę rozdamy wszystkim naszym członkom, a to $w$ tym celu, ażeby się wypowiedzieli co do tej organizacji. Po otrzymaniu tej prasy wszyscy wstąpiliśmy do organizacji BCh", AIPN Ki_0_13_1138_t2_cz2, k. 227.

19 Przesłuchanie podejrzanego Edwarda Grudnia, 15.6.1950, Ki_0_27_165, K. 192.

20 "Założycielem Stronnictwa Narodowego w Sędziszowie był wikary Stefan Wieniawski [lub: Niewiarski] [...] przed 1939 w kościele na kazaniach nawoływal do bicia ludzi narodowości żydowskiej, żeby nikt u nich nie kupował oraz inne rzeczy skierowane przeciwko tej narodowości"; AIPN Ki_0_13_1138_t2_cz1, k. 49 i dalej.

21 Niektórzy z nich, jak Marian Grombala (s. Andrzeja, ur. 25.1.1916 w Gieraszowicach) służyli we wszystkich formacjach policyjnych: policji przedwojennej, granatowej i komunistycznej, zob. Przesłuchanie podejrzanego Mariana Grombali, AIPN Ki_0_13_1185_t1, K. 187.

22 Jan Ryczko był przedwojennym policjantem na Kresach, następnie w Radziłowie na Podlasiu; po wojnie wstąpił do MO w Jędrzejowie, AIPN Ki_0_13_1138_t1, k. 34, 75, 125.

23 W granatowej policji, a w komunistycznej po wojnie był także Władysław Janowski, introligator, który miał na sumieniu kilkudziesięciu Żydów,w tym dwoje dzieci, Zelka i Dorę, które przyszły po żywność do wsi Strzegom; Ki_0_13_1036, k.24; zob. też: J.Tokarska-Bakir Pod klątwą. Społeczny portret pogromu kieleckiego, Czarna Owca, t. 1, Warszawa 2018, s. 514-515.

24 Antoni Jarosz, podoficer zawodowy w WP, po wojnie kwatermistrz w KW MO Kielce; zob. tamże, s. 515 .

25 Wacław Tutak ps. Brzoza - do 1939 podoficer w WP, komendant Strzelca W 4 gromadach, Ćwiertnia 7, 305; zob. tamże, s. 555.

26 Jan Osemlak (s. Walentego, ur. 7.10.1921W Łoniowie), Ki_013_4124: k. 37: listonosz w Agencji Pocztowej w Łoniowie, był w Strzelcu, potem w AK.

27 Stanisław Czerwiec, uczestnik mordu na Żydach w Bełzowie, po wojnie komendant MO w Kościelcu; pracował w Kościelcu jako agronom. 
W mordzie w Bełzowie, gdzie w grudniu 1943 roku rozstrzelano rodziny Ptaśników i Czosnków, bierze udział nauczyciel Smoliński ${ }^{\mathbf{2 8}}$. Po seminarium nauczycielskim jest też dowódca tej akcji, Edward Szczęsny, wysiedleniec z Poznańskiego ${ }^{29}$. Ten przedwojenny oficer nie tylko dał rozkaz likwidacji dziewięciorga Żydów, w tym czterech kobiet, ale też sam do nich strzelał po odebraniu im pieniędzy i kosztownosci.

Inny uczestnik mordu, Edmund Sędek, który będzie ukrywał się aż do roku 1956, gdy ujawni się przed radiową „Falą 56”, „od 1941 chodził do prof. Nitscha na kurs języka niemieckiego i księgowości”30 . Kolejnym sprawcą jest Stanisław Knaś (Kuraś?), przedwojenny inkasent w Państwowych Zakładach Ubezpieczeń Wzajemnych ${ }^{31}$.

Wielu sprawców nosi inteligenckie pseudonimy: Ramzes, Saturn ${ }^{32}$.

Inni - o pseudonimach Skrzetuski ${ }^{33}, Z_{\text {Zagłoba }}^{34}$ i Wołodyjowski ${ }^{35}$ - są urzędnikami w miejscowej gminie.

Można powiedzieć, że to właśnie Skrzetuski z Wołodyjowskim z pomocą Zagłoby i nauczyciela Szczęsnego ps. Bogusław zabili dziewięcioro Żydów w Bełzowie ${ }^{36}$.

\section{Prowincja noc?}

Kielecka wieś w okresie okupacji nie jest jakąś odseparowaną od świata pustynią społeczną, którą toczy podstępna, narzucona przez Niemców anomia.

28 Ki_o_27_165, k. 86.

29 Ki_126_352, k. 192. Edward Szczęsny, ps. Bogusław, s. Franciszka i Marii Marzec, ur. 16.6.1910 w Samborze, nauczyciel, komendant rejonu BCh i inspektor szkoleniowy. M.in. za zabójstwo 9 Żydów w Bełzowie 11.1.1951 wyrokiem Sądu Wojewódzkiego w Kielcach skazany na karę śmierci, 10.3.1958 złagodzoną do 12 lat więzienia, zm. 11/7/1962.

AIPN Ki_126_353, k. 24 .

Ni_0_27_165, k.162. Stanisław Knaś [Kuraś?], s. Leona i Józefy Słupnik, ur. 19/.8.1905 w Donatkowicach gm. Dobiesławice pow. Pińczów. 
Nic podobnego. Oprócz wspomnianych formacji samoobrony działają tu organizacje takie jak Ochotnicza Straż Pożarna, pomagająca okupantowi wyłapywać Żydów po likwidacji gett. Partyzanci AK i BCh są zaopatrywani w broń z londyńskich zrzutów ${ }^{37}$. W ich trakcie na przełomie 1943-1944 w rejonie Jędrzejowa ląduje aż sześciu cichociemnych. Każdy z nich bez trudu znajduje bezpieczne schronienie - w majątkach albo na plebaniach - gdzie jednak nie ma miejsca dla Żydów ${ }^{38}$.

\section{Jak sami członkowie samoobrony BCh i AK mówią o tym, co robią Żydom?}

W Pińczowskiem mówi się o tym bez owijania w bawelnę: przeprowadziliśmy „[cztery] akcje likwidacyjne przeciwko obywatelom polskim narodowości żydowskiej”39. Albo: „idziemy likwidować Żydów, przechowujących się u jednego gospodarza"40. Nie jest to terminologia lokalna, występuje też w innych rejonach: „po zlikwidowaniu ośmiu żydków pod Kazimierzą Wielką..." Albo: „oddział nasz [AK] ma stawić się koło szkoły w Chruszczynie Wielkiej celem udzielenia pomocy Korpusowi Bezpieczeństwa [BCh], który w Chruszczynie miał przeprowadzić likwidację żydów"42.

Dowódca jednej z akcji preferuje określenie „robota”: „Widząc, że robota

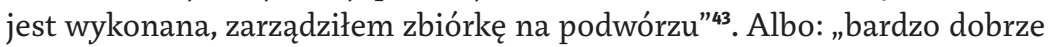
udała nam się robota"44.

W meldunkach tajnych wspópracowników eufemizmów już nie ma: „donoszę, że Żydków w Bełzowie wymordowali członkowie Korpusu

37 Zob. np. zrzut w maju 1944, AIPN Ki_0_27_165, k.141.

38 Gdy okazują się Żydami - jak nauczycielka francuskiego w Pawłowicach gm. Sędziszów - napiętnowani jako komuniści muszą opuścić dwór i giną, AIPN Ki_0_13_1138_t1, k. 62, 208. Przesłuchanie podejrzanego Stefana Drewno, AIPN Ki_0_27_165, k. 143. Tamże. AIPN Ki_126_351, k. 243. AIPN Ki_0_27_165, k. 143, k. 193. W Chruszczynie Wielkiej zginęła rodzina Dulów, którzy prowadzili przed wojną sklep bławatny w Kazimierzy Wielkiej. Zostali tam zamordowani Idel Dula i jego żona Ester oraz dzieci Kalman, Frania, Rfika i Wolf (informację o imionach ofiar zawdzięczam Tadeuszowi Koziołowi, autorowi publikacji o martyrologii Żydów we wsi Chruszczyna Wielka). Przesłuchanie podejrzanego Stanisława Kozery, 20.7.1950, AIPN GK 375_7 PSA Kiel 426, k. 26. 
[Bezpieczeństwa BCh] i członkowie Korpusu Styka. «Styk» to jest Styczeń Aleksander [powinno być: Aleksy]"45.

Dlaczego „Żydków się morduje”? Bo samoobrona BCh i dywersja AK mają obowiązek „utrzymania porządku na terenie" ${ }^{\text {"46 }}$, a ofiary uważa się za wrogów tego porządku. Powyższe dowódca plutonu AK w Ćmielowie Jan Pękalski, od połowy 1943 roku oficer personalny obwodu Opatów, tłumaczy następująco: "Co do stosunku naszej organizacji do ludzi narodowości żydowskiej, to był rozkaz, oczywiście nieoficjalny, likwidowania Żydów, o czym było wiadomo każdemu członkowi AK"47.

\section{Metodologia}

Inspiracją niniejszego tekstu był artykuł Johna P. Reedera Jr What kind of person could be a torturer? ${ }^{28}$, stanowiący próbę fenomenologicznego ujęcia motywów kierujących osobami, które współcześnie - w służbie państwa, religii lub ideologii - dopuszczały się tortur. Autor szczególnie skoncentrował się na przypadku Abu Ghraib i pinoczetowskiego Chile.

Wzorując się na zastosowanej przez autora metodologii performatywnej, zrekonstruowane przypadki mordów traktuję jak historyczne dramaty obserwowane z widowni49. Główną rolę odgrywają w nich sprawcy czy raczej oprawcy $(\text { torturer })^{50}$, gdyż prześladowania, których dopuścili się wobec ofiar,

45 TW ps. Jaszczurka, 5/11/1949, AIPN Ki_0_27_165, k. 86. Aleksy Styczeń, s. Franciszka i Agnieszki Janczur, ur. 31.8.1923 w Wolwanowicach gm. Kościelec, pow. Pińczow.

46 Ki_o_27_165, k. 193. Cele korpusu „Dominika”: „walka dywersyjna z Niemcami, zdobywanie broni, szkolenie się, kara chłosty współpracownikom niemieckim, utrzymywanie porządku na terenie, zabezpieczenie przed kradzieżami, niszczenie papierów kontyngentowych", tamże, k. 192.

Przesłuchanie podejrzanego Jana Pękalskiego, 4/7/1949, AIPN Ki_013_173, k. 68.

J.P. Reeder Jr What kind of person would be a torturer, s. 67-92.

"As I watch the play, I gradually begin to interpret and explain the charakters that I observe that is, I form hypotheses about the characters of charakters involved", J.P. Reeder Jr What kind of person would be a torturer, s. 69. W niniejszym komunikacie nie ma miejsca na rozwinięcie wątku tych charakterystyk, które będą zasadniczym zadaniem zapowiadanego tu artykułu. cierpienia fizycznego i psychologicznego dla osiągnięcia określonych celów politycznych, np. uzyskania informacji, aby go ukarać, lub zastraszyć", za: J.P. Reeder Jr What kind of person would be a torturer, s. 67. W znaczeniu szerszym tortura definiowana jest (za: W. Cavanaugh Torture and Eucharist: theology, politics and the Body of Christ, Blackwell, Oxford 1998, s. 2, 23, 30) 
nie ograniczały się do egzekucji ludzi, których uznali za „niemieckich konfidentów”, ,niemieckich sprawców”, członków „band rabunkowych”,,,członków NSZ", ,gwałcicieli" czy po prostu „ludzi podejrzanych".

Kobiety były gwałcone ${ }^{51}$.Zdarzało się, że rozstrzeliwano je, gdy zachodziły w ciążę ze sprawcami. Taki los spotkał Rywkę Fajnkuchen, lat 17, która przez dłuższy czas była służącą u Daniela Stawiarza, buchaltera z Osieka, pow. Sandomierz ${ }^{52}$, a wcześniej u Franciszka Jońcy.

Schwytanych Żydów zwodzono co do ich losu, starając się wydobyć od nich jak najwięcej zasobów finansowych i rzeczowych ${ }^{53}$. Ofiarom mordu w Bełzowie powiedziano, ,żeby się nic nie bali, bo nad dołami z wytłokami buraczanymi [dowódca oddziału Edward Szczęsny, nauczyciel] postawił ich

jako „pewien rodzaj teatru, w którym ludzie są zmuszani do ogrywania ról, które wzmacniają pewien typ wyobraźni społecznej" (s. 314-315), narzuconej ludziom przez państwo, dyscyplinującej ich ciała, przyzwyczajającej ich do pewnych rzeczy i wdrażającej im scenariusze własnej produkcji. Atomizuje ona społeczeństwo za pomocą strachu, demontując inne formy organizacji, które mogłyby mu zagrażać. Ofiara tortury musi przyznać się, że jest wrogiem państwa, i w tym sensie ofiary nie tyle karze się, ile produkuje", J.P. Reeder Jr What kind of person would be a torturer, s. 69 przyp. 7

51 Przesłuchanie podejrzanego Bolesława Woźniaka, 27.7.1950, AIPN Ki_013_1185_t1, k. 184: „Po dojściu pod dom Zwolskiego Franciszka gdzie były przechowywane ww. osoby ja zostałem przy furmance jako furman, a dowódcy jak Ćwiertnia, Jarosz, Gradzik, Pałka weszli do wnętrza, gdzie ze strychu nad mieszkaniem ściągnęli ukrywające się tam 5 osób, a także zabrali ich walizki, w których były drogocenne rzeczy, jak złoty zegarek, ubrania, inne drogie rzeczy, które były w paru walizkach. Rzeczy te wzięli zaraz pod swoją opiekę dowódcy na wóz. Po zabraniu tych rzeczy wszyscy wraz z tymi osobnikami i zrabowanymi rzeczami udaliśmy się w kierunku wsi Przewłoka [...] Po dojechaniu razem do Krzcina tam się podzieliliśmy na dwie grupy, jedna pojechała do wsi Przewłoka [...] ze zrabowanymi rzeczami, tj. Ćwiertnia, Jarosz, Sroczyński i ja jako furman, a druga grupa z tymi pięcioma osobami udali się do wsi Zarudcze [...] do ob. Rożka, gdzie te osoby ulokowali w stodole, gdzie byli zatrzymani parę dni. Po paru dniach zostały wymienione osoby rozstrzelane przez Pałkę Mariana, Gradzika Czesława i Staszczaka Stanisław zam. Krzcin. [...] W rozmowie z Gradzikiem Czesławem mówił, że «jest dobra okazja, to się przy tym popieprzy», i powiedział, że «Pałka Marian to może sześć razy, i ja też poszedłem», tzn. że przed zamordowaniem gwałcili te kobiety, które były Polki".

AIPN Ki_0_13_1036, k.33.

53 Na przykład w trakcie kursu podoficerskiego Antoni Jarosz zaproponował Marianowi Grombali, aby "pojechali po majątek żydowski do Koprzywnicy”. Chodziło o Żyda młodego z Trzykos, „imię jego było Srulik". Jarosz "mówi do tego Żyda: «pojedziesz z temi chłopakami i pozbierasz, gdzie masz jaki majątek, i będziesz z temi chłopakami jeżdził, i nie będziesz siedział w kryjówce». Dali mu wtedy karabin i poszliśmy do Koprzywnicy, i tam byliśmy w paru domach, zabierając jego majątek [...] przyzwyczaili do siebie tego Żyda, i tak ściągnęli z niego majątek przez okres dwóch tygodni. Kiedy już majątki się skończyły, to oni i Żyda skończyli", Ps. Młot, relacja z opowiadania Antoniego Jarosza, Ki_013_1185_t1, 112. 
tylko aby nie uciekali. Następnie powiedział do Żydów, że my jesteśmy wojskiem polskim i z tego powodu nie grozi im nic, lecz muszą oddać wszystkie wartościowe przedmioty i pieniądze na rzecz dozbrojenia wojska polskiego" ${ }^{54}$.

Wszystkie wspomniane prześladowania nie były izolowanymi aktami bandytyzmu, ale zachowaniami seryjnymi, których korzenie tkwią „w określonych scenariuszach lub lub praktykach społecznych"55.

\section{Konsekwencje sprawstwa}

Charakter działania sprawców, najpierw współdziałających z okupantem w organizowaniu obław na Żydów, potem zaś, wykorzystując przekupstwo i donos sąsiedzki, na własną rękę systematycznie patrolujących okolicę w poszukiwaniu Żydów, kwalifikuje ich czyny jako ludobójstwo ${ }^{56}$. Żydzi zabijani są tu bez względu na wiek, płeć, poglądy, zasługi (jedna z ofiar to ukrywający się na prowincji przedwojenny oficer WP). Zawsze przed egzekucją sprawdza się, czy mężczyźni są obrzezani".

W rezultacie zabójstw zmieniali się przede wszystkim sami ich sprawcy, a zamieszkiwany przez nich tradycyjny świat przekształcał się w dystopię, której reguły ustalał gang zabójców, mieniących się jego patriotycznymi strażnikami.

Rutyna mordowania kładła się cieniem na terroryzowanej wsi, na której zagrożeni byli nie tylko Żydzi, ale także ci Polacy, którzy zdecydowali się ich ukryć. Gospodarze, którzy naprawdę nie chcą wydać swoich Żydów (co nie zawsze się zdarzało ${ }^{58}$ ), prawie zawsze są maltretowani przez dokonujących

54 Ki_o_27_165, k. 226.

55 J.P. Reeder Jr What kind of person would be a torturer, s. 68.

56 Zgodnie z terminologią międzynarodową każdy grób w którym złożono więcej niż trzy osoby staje się z definicji „masowy”, zaś każdy mord, którego sprawcy kierowali się ideą wyniszczenia całej grupy etnicznej, z definicji uzyskuje miano ludobójstwa. Nie można orzec ludobójstwa, jeśli się nie udowodni, że celem sprawców było wymordowanie - „w całości lub w części”, jak stanowi stosowna konwencja ONZ - "grupy narodowej, rasowej, etnicznej lub religijnej” ofiar.

57 Ki_013_1185_t1, K. 281: „jesienią 1943 na łąkach obrazowskich [Kostrzewa] zatrzymał człowieka nieznanego pochodzącego ze Skarżyska, ktory przyjechał celem kupienia artykułów żywnościowych (Szmuklarz [niejasne, czy chodzi o szmuglera, czy o nazwisko]), gdzie przez grupę «Róży» [pseudonim Kostrzewy] został on rozebrany do naga celem dokonania oględzin czy nie jest obywatelem polskim narodowości żydowskiej".

58 Zob. np. historia Tojwy przechowywanego przez wdowę Madejową. Między ukrywanym a gospodynią dochodziło do sprzeczek z powodu opłat za ukrywanie się: „Tojwa nie chciał jej za- 
rewizji partyzantów. Co najmniej raz w trakcie poszukiwania Żydów banda zabija rodzinę, która ich ukrywała. Antoni Osmala s. Błażeja dokonuje tego mordu we wsi Wygoda gm. Czyżów Szlachecki. Giną też ukrywani tam Żydzi ${ }^{59}$.

Zagrożeni są w ogóle wszyscy, którzy odważają się „postawić się” gangowi „samoobrony”. Przede wszystkim wycina się konkurencję, np. masarza Berczyńskiego, którego chce się pozbyć rywalizujący z nim rzeźnik Stefan Bernacik $^{\mathbf{6 0}}$. Rozpowiada więc, że Berczyński jest komunistą i wkrótce nie ma już konkurenta.

Bite i gwałcone są także chłopki, które nie chcą sypiać z partyzantami ${ }^{61}$, szczególnie te, które wyśmiewają ich tchórzostwo ${ }^{62}$. Niektóre z tych kobiety zabija się, bo widziały morderstwo albo były świadkiem gwałtu.

Zdarzają się akcje, w których kobiety stanowią większość ofiar. Na przykład ta, w której wybito rodzinę członka BCh, który skłócił się z kolegami. W nocnej akcji zabijają więc oni jego, dwie siostry, ciotkę i starego ojca. Jedyny ocalały z masakry brat wyjedża po wojnie do USA, i tak ród Jąderków znika z Sędziszowa ${ }^{63}$.

Miarą rozpadu świata jest sytuacja, o której mówi następująca relacja: „Na polu pod lasem [tzw. grodeckim, czyli k. Gródka] obok Sędziszowa była wykopana studnia. Obok tej studni miał sobie stawiać dom niejaki Brzeziński, bo ta studnia była jego i na jego polu. [...]. Pewnego dnia, a było to latem 1943, Brzeziński z żoną przyszli oglądać swoje pole, na którym była ta studnia. Przypadkowo zajrzeli do tej studni i zauważyli jakieś coś na dnie, ponieważ dzień był pogodny, a z dna tej studni wydobywał się straszny smród. Przyszli wtedy

płacić, wtedy Madejka udała się do Osemlaka Jana [...] wiedząc o tym, że należy do partyzantki i posiada broń i oznajmiła mu, że u niej przechowuje się Żyd. Tego samego dnia Osemlak udał się do zabudowań Madejki, gdzie zastał Tojwę, którego wyprowadził na stodołę i zastrzelił", AlPN Ki_013_4124, k. 35.

59 Ki_0_27_165, k. 136.

60 AIPN Ki_o_13_1138_t3, k. 27.

61 AIPN Ki_0_13_1138_t3, k. 38: „Sałówna Stanisława zginęła (kwiecień 1944), bo nie chciała być kochanką «Blondyna». Zaznaczam, że ona była pracowniczką gminy Sędziszów i wyrobiła wszystkim z organizacji lewe dowody".

62 AIPN Ki_0_13_1138_t1, k.36. Słokowa miała jak najlepszą opinię; zostawiła dziewięciomiesięczne dziecko; jej mąż został zamordowany przez Niemców za BCh; zeznający wyraża przypuszczenie, że zamordowano ją, bo „śmiała się z nas, co my za bohaterzy, że tak uciekamy przed Niemcami".

63 AlPN Ki_0_13_1138_t2_cz1, k. 18-19. 
oboje do Sędziszowa i o tem co zauważyli w swojej studni zaczęli opowiadać. Było kilku ciekawskich, co poszli tę studnię ogladać. Tam właśnie w tej studni były ciała pomordowanych przez miejscową dywersję AK. Tej samej nocy miejscowa dywersja pod terrorem wzięli studniarza Stefana Butkowskiego z Sędziszowa, który do dzisiejszego dnia mieszka w Sędziszowie, i na powrozie wpuścili go do tej studni, by wyciąał te trupy. W tej studni było 17 czy 18 zgniłych i na wpół gnijących ciał ludzkich. Między innymi był tam też trup mojego ojca"64 - mówi świadek na procesie w latach pięćdziesiątych.

Studnia to nie jest na wsi taka zwykła rzecz. Jest potrzebna, aby powstała osada, i w tym sensie jest ona warunkiem życia. Świat staje na głowie, kiedy studnia staje się grobem.

\section{Klasyfikacja sprawców}

Skala postaw sprawców zarysowanych w artykule Johna P. Reedera rozpoczyna się od postaw jednoznacznych i zmierza ku bardziej zniuansowanym. Przejmuję za nim te kategorie w klasyfikacji sprawców mordów.

1. Pierwszą kategorię stanowi czysto abstrakcyjny sadysta, czyli sprawca nieempatyczny ${ }^{65}$; ma zdolność do empatii zablokowaną, skarłowaciałą lub zdeformowaną ${ }^{66}$.

2. Kolejne dwie pozycje to sprawca „obojętny” (ani sadysta, ani człowiek współczujący) ${ }^{67}$,

3. A także sprawca „bezmyślny”, niebędący w stanie zająć jednoznacznie pozycji - empatii lub jej braku (wanton torturer); jest wprawdzie w stanie zobaczyć cierpienie ofiary, ale „nie potrafi [stabilnie] się z nią zidentyfikować"68.

4. Bardzo powszechną postawę reprezentuje sprawca "posłuszny”, który po prostu wykonuje rozkazy. Pojmuje on swój obowiązek jako moralnie i prawnie usprawiedliwiony, nie doświadczając konfliktu moralnego.

64 Zeznanie Zygmunta Barczyńskiego, 20.9.1949, AIPN Ki_0_13_1138_t3, k. 33.

65 Empatię definiuje się tu jako zdolność wyobrażenia sobie cudzego cierpienia, J.P. Reeder Jr What kind of person would be a torturer, s. 71 i przyp. 17.

66 Zarówno dla sadyzmu, jak i współczucia empatia jest warunkiem koniecznym, ale niewystarczającym; potrzebne są jeszcze takie elementy jak poglądy moralne, konsekwencja, stabilność, odpowiedzialność, zdecydowanie.

67 J.P. Reeder Jr What kind of person would be a torturer, s. 72.

68 Tamże, s. 73. 
Może mieć współczucie dla ofiar, ale akceptuje torturę jako wyższą konieczność, militarną lub polityczną.

5. Jeszcze dalej na skali sytuuje się sprawca „sprawiedliwy”, posiadacz silnych przekonań, akceptujący nieakceptowalne środki w nadzwyczajnej sytuacji.

6. Klasyfikację zamyka „realista”: odsuwa on na bok wszelkie moralne skrupuły ze względu na założony cel polityczny, np. dobrostan własnej grupy etnicznej ${ }^{69}$.

Na miano sprawcy empatycznego stara się zasłużyć Tadeusz Styczeń, który szczegółowo opisuje rozstrzelanie Żydów w Bełzowie, ustawianie dziewięciu osób nad rowem, zdejmowanie zegarków. Ale nie podaje nazwisk kolegów, którzy strzelali: „Kto bezpośrednio strzelał dokładnie powiedzieć nie mogę, ponieważ [...] nie mogłem patrzeć na żydków, które czekały na śmierć"70.

W podobnie niewiarygodny sposob broni się Stanisław Kozera, z oddziału dywersyjnego 106 Dywizji Piechoty AK Okręg Kraków baonu „Zagraj”, dowódca akcji w Chruszczynie Dużej. Twierdzi, że jego akowski oddział miał tylko asystować grupie dywersyjnej $\mathrm{BCh}$, a on sam był pozbawiony mocy decyzyjnej: „ja swój oddział rozstawiałem wkoło zabudowania, gdzie mieli znajdować się żydzi, sam zaś chodziłem po podwórku i po drodze. Natomiast oddział K[orpusu] B[ezpieczeństwa [BCh] przeprowadzał rewizję. [...] weszli do stodoły i wtedy znaleźli 5 osób pochodzenia żydowskiego. Po wyprowadzeniu ich na boisko ja zaświeciłem lampką pytając ich, co mają zamiar z nimi zrobić, na co dostałem odpowiedź, że mają rozkaz zlikwidować, czyli zastrzelić. Na co ja nie chciałem się zgodzić. Natomiast oddział KB był zdecydowany, aby znalezionych żydów zabić. Wobec takiej odpowiedzi oddział KB zabrał ujętych żydów i poprowadził ich do ogrodu tegoż gospodarza, po

69 W listopadzie 1943 roku sześcioro Żydów ukrywało się w schronie pod stodołą w zabudowaniach Stanisław Stefaniaka, Kolonia Połaniec. Podobno doniósł Kazimierz Anioł (s. Wawrzyńca, ur. 19.6.1923 w Rudzie). Morderstwo następująco uzasadnił Szczepan Chyla (s. Aleksandra, ur. 24.12.1915): „W Połańcu są Żydzi pijawy, których trzeba wybić”. Żydzi byli zabijani kolejno strzałami w głowę. Zrabowano ich własność, a także garderobę i bieliznę ukrywającej ich rodziny Stefaniaków, których ciężko pobito za przechowywanie Żydów. Jan Kurgan (s. Michała, ur. 15.2.1918, w latach 1942-1944 komendant placówki AK na terenie Tursko Wielkie pow. Jędrzejów) powiadomiony o mordzie kazał zrabowane pieniądze przekazać kasie Obwodu BCh, Ki_9_28_t2_cz1, k. 6-8. 
czym posypały się strzały. Kto dał rozkaz strzelania nie jest mi wiadomym, i kto bezpośrednio strzelał tych żydów, tego nie wiem"71.

Taka affective ignorance - pozorowana niewiedza ${ }^{72}$ - stanowi wymówkę pozwalającą nie wchodzić w szczegóły zbrodni. Jeden z uczestników mówi: „biorąc udział w tej akcji nie wiedziałem o tym, że morduję obywateli polskich narodowości żydowskiej i dopiero 2 dni po w/w akcji dowiedziałem się od ludzi, iż zamordowałem Żydów, a nie konfidentów"73.

Dowódca akcji w Bełzowie, Edward Szczesny ps. Bogusław (ten sam, który uspokajał Żydów, że wojsko polskie ich nie skrzywdzi, jeśli tylko oddadzą pieniądze), posługuje się podobną strategią. Zaprzecza, że kierował rozstrzelaniem, opowiada jak postronny widz, który nie wiadomo dlaczego znalazł się na scenie. Charakterystyczne są elementy cynicznie „pozorowanej niewiedzy": „...z ciekawości podszedłem bliżej”, „....spytałem się, czy akcja się udała i na co otrzymałem odpowiedź, że się udała”, „....wkrótce we wsiach usłyszałem że w Bełzowie zabito Żydów. Udałem się z tą wiadomością do dowódcy Wojnara, to ten się zdziwił"...74.

Rzadko z ust sprawców pada świadectwo opisujące skutki podjętych czynów, na przykład rany ofiar. W Chruszczynie: „na odgłos strzałów pobiegłem w tym kierunku i zachodząc za stodołę [Kazimierza] Sodo zobaczyłem tam kilka zastrzelonych Żydów. [...] Ile trupów dokładnie nie pamiętam, pamiętam tylko że między zabitymi były kobiety i mężczyźni, a trupy zastrzelonych, szczególnie czaszki, były bardzo roztrzepane od strzałów seryjnych"75.

\section{Typ świadectwa sprawcy: nieciągłość i dezorientacja}

Przeciętne świadectwo sprawcy mordu w Chruszczynie czy Bełzowie mówi, że gdzieś w świecie nastąpiło zerwanie, zakłócenie czasoprzestrzeni i zeznający nic nie pamięta. Świadectwo jego à rebours akcentuje to, co świadek usiłuje przemilczeć. Na różne sposoby stara się on bowiem przekroczyć, pomniejszyć,

\footnotetext{
71 Przesłuchanie podejrzanego Stanisława Kozery, 22.5.1950, AIPN Ki_0_27_165, k. 171.

72 Pojęcie Michelle Moody-Adams, za: J.P. Reeder Jr What kind of person would be a torturer, s. 77.

73 AIPN Ki_126_341, k. 91.

74 Tamże, k. 70.

75 Stanisław Stasik, ps. Ropucha, s. Kazimierza i Marii Żurek, ur. 10.4.1919 w Przeczniowie, gm. Nagorzany, pow. Pińczów, AIPN Ki_0_27_165, k. 224.
} 
zignorować krytyczne wydarzenie. Odwraca wzrok, ale nie może nad nim zapanować. Chwila nieuwagi i oko jest znów w punkcie wyjścia.

Sprawca usiłuje pogodzić samowiedzę z samooceną: efektem jest pogłębiająca się dezorientacja. Tak rodzi się decyzja o zerwaniu z rzeczywistością i potrzeba historii wyidealizowanej. Realna jest bowiem nie do zniesienia.

Metodyka fałszywego świadectwa jest następująca: sprawca rozwodzi się o przygotowaniach do czynu (rano wstałem, umyłem się, zjadłem śniadanie) i drobiazgowo omawia jego nieistotne następstwa (podjechały podwody, załadowaliśmy towar, $\mathrm{X}$ dostał popielaty garnitur, a jego żona białe płótno na suknie). Sam czyn jednak pomija, kwituje pojedynczym zdaniem lub opisuje z dalekiej perspektywy: Nie było mnie tam. Byłem chory lub źle poinformowany. Pilnowałem koni. Zostałem przy saniach. Stałem na obstawie 35 albo 150 m od stodoły, gdy usłyszałem strzały karabinowe. Dopiero po dwu dniach we wsi usłyszałem, kogo zabito.

Tak mówią też dowódcy, szefowie jednostek dywersyjnych AK, komendanci LSB.

Po wojnie wielu z nich trafia do Milicji Obywatelskiej.

\section{Abstract}

\section{Joanna Tokarska-Bakir}

THE INSTITUTE OF SLAVIC STUDIES, POLISH ACADEMY OF SCIENCES

The Month-Brothers: Perpetrators'Testimonies

Based on archival research at the Institute of National Remembrance (IPN), Tokarska-Bakir explores the murders of Jews committed by diversionary units of Peasant Battalions and the Home Army in the southern Kielce region during the third phase of the Holocaust.

\section{Keywords}

perpetrators' testimonies, third phase of the Holocaust, murders of Jews, diversion units of the Bataliony Chłopskie and Armia Krajowa, Farmers' Battalions, Home Army 